\title{
Potensi dan Implementasi Zakat Pertanian Di Desa Akeguraci Kecamatan Oba Tengah Kota Tidore Kepulauan
}

\author{
Nursinita Killian ${ }^{1}$ \\ Institut Agama Islam Negeri (IAIN) Ternate \\ doi https://doi.org/10.32507/mizan.v4i2.817
}

\begin{abstract}
This article discusses the potential and implementation of agricultural zakat in Akeguraci village. The aim of this research is to studies the level of understanding and knowledge of the Akeguraci village farmers in the obligation of paying for zakat, especially agricultural zakat. The method used in this research is a qualitative descriptive analysis based on field research, in the form of direct observation, interviews, and documentation. The result of this research indicates that the Akeguraci village farmers are included in both categories for calculating zakat and paying for zakat. Although included in the good categories, Akeguraci village farmers still have a minimum of knowledge about agricultural zakat, therefore they have not been able to calculate agricultural zakat correctly and accordance with Islamic Law. Besides in paying zakat, farmers are still relatively dependent on their level of awareness, while in Islamic Sharia it has been determined that zakat of agricultural products is an obligation.

Keywords: Potential, Implementation, Agricultural Zakat
\end{abstract}

\begin{abstract}
Abstrak
Artikel ini membahas tentang potensi dan implementasi zakat pertanian di desa Akeguraci. Dengan tujuan untuk mengetahui sejauh mana tingkat pemahaman dan pengetahuan masyarakat tentang kewajiban pembayaran zakat secara umum dan zakat pertanian secara khusus. Artikel ini menggunakan penelitian deskriptif kualitatif berbasis penelitian lapangan (field research), dengan pendekatan deskriptif kualitatif dan teknik analisis kualitatif berupa hasil observasi, wawancara, dan dokumentasi. Hasil penelitian ini menunjukkan bahwa masyarakat Desa Akeguraci baik dalam menghitung zakat maupun membayarkannya masih relatif tergantung kepada tingkat kesadaran dari para petani sendiri. Zakat yang mereka keluarkan seadanya saja dikarenakan pengetahuan tentang zakat pertanian yang masih minim. Petani Desa Akeguraci belum mengetahui cara menghitung zakat pertanian sesuai dengan syariat Islam yang mewajibkan adanya kewajiban zakat pada hasil pertanian.
\end{abstract}

Kata Kunci: Potensi, Implementasi, Zakat Pertanian

* Naskah diterima tanggal: 13 September 2020, direvisi: 13 Oktober 2020, disetujui untuk terbit: 10 Desember 2020.

${ }^{1}$ Nursinita Killian adalah dosen tetap pada Institut Agama Islam Negeri (IAIN) Ternate. Email: nursinita@iain-ternate.ac.id. 


\section{A. PENDAHULUAN}

Menurut hukum Islam, zakat adalah suatu bagian tertentu dari harta yang telah mencapai nisabnya, yang dibayarkan oleh seorang muslim dengan cara pengalihan kepemilikan kepada orang-orang yang berhak menerimanya. Berdasarkan ajaran agama zakat merupakan salah satu rukun Islam dan diwajibkan kepada umat Nabi Muhammad SAW pertama kali di Mekkah dalam bentuk yang masih mutlak, tanpa batasan jenis dan jumlah harta yang wajib dizakati sebagai bentuk kebaikan, harga diri dan kedermawanan seorang Muslim. ${ }^{2}$ Setelah Rasulullah SAW hijrah ke Madinah tepatnya pada tahun ke-2 Hijriyah, ketentuan tentang jenis dan jumlah harta yang wajib dizakati diatur dengan aturan yang terinci. ${ }^{3}$ Zakat termasuk dalam kategori ibadah seperti shalat, haji dan puasa, yang telah diatur secara rinci berdasarkan Al-Qur'an dan As-Sunnah namun sekaligus juga merupakan amal sosial kemasyarakatan dan kemanusiaan yang dapat berkembang sesuai dengan perkembangan umat manusia.

Salah satu jenis zakat yang sangat potensial di Indonesia adalah zakat pertanian. Menentukan muzakki dari zakat pertanian secara kasat mata sangat mudah dan banyak, karena Indonesia merupakan negara agraris dan penghasilan rata-rata rakyat Indonesia berasal dari hasil pertanian bahkan menjadi penghasilan masyarakat ekonomi menengah ke bawah. Zakat hasil pertanian merupakan zakat yang unik dan berbeda dengan beberapa kategori zakat harta lainnya, zakat pertanian dikeluarkan ketika panen tanpa menunggu berjalan setahun (haul) dan nisabnya relatif lebih kecil dari pada zakat harta lainnya namun kadar pengeluarannya lebih besar yaitu antara 5\% dan 10\%. Zakat pertanian merupakan zakat yang paling mudah dan cepat untuk ditunaikan, ditambah lagi kebiasaan panen di suatu tempat dalam waktu serentak atau mengikuti musim, seperti yang terjadi di Desa Akeguraci Kecamatan Oba Tengah Kota Tidore Kepulauan.

Desa Akeguraci Kecamatan Oba Tengah Kota Tidore Kepulauan yang sebagian besar penduduknya berprofesi sebagai petani, memiliki lahan pertanian yang luas dan banyak. Oleh karena itu potensi hasil pertanian di Desa Akeguraci pada setiap panennya sangat banyak, namun terungkap bahwa setiap hasil pertanian atau perkebunan yang didapat oleh para petani Muslim di Desa Akeguraci belum ditunaikan zakat pertaniannya. Masyarakat Desa Akeguraci hanya mengeluarkan zakat maal pada akhir Bulan Ramadhan. Bagi peneliti diperlukan penelitian secara mendalam agar potensi pertanian yang besar ini dapat membangun desa yang lebih sejahtera melalui pengelolaan zakat hasil pertanian. Selain itu penelitian ini juga diharapkan dapat memberikan pemahaman tentang kewajiban zakat pertanian kepada masyarakat Desa Akeguraci Kecamatan Oba Tengah Kota Tidore Kepulauan.

\section{B. METODE PENELITIAN}

Artikel ini menggunakan penelitian deskriptif kualitatif berbasis penelitian lapangan (field research), dengan pendekatan deskriptif kualitatif dan teknik analisis kualitatif berupa hasil observasi, wawancara, dan dokumentasi.

\footnotetext{
2 Muhammad Sayyid Thonthowi, Al-Figh al-Musayyar (Cet. I; Kairo: Dar as-Sa'adah, 2001), h. 123.

${ }^{3}$ Wahbah az-Zuhaily, Al-Figh al-Islami wa Adillatuhu (Juz II; Beirut: Dar al-Fikr, t.th), h. 733.
} 


\title{
C. ANALISIS DAN PEMBAHASAN
}

\section{Konsep Zakat Pertanian Menurut Hukum Islam}

Zakat pertanian merupakan proses pelaksanaan hak yang wajib dari harta atau hasil pertanian (semua yang ditanam menggunakan biji-bijian yang hasilnya dapat dimakan oleh manusia dan hewan). ${ }^{4}$ Dapat dikatakan bahwa zakat pertanian merupakan salah satu jenis zakat maal. Objeknya meliputi hasil tumbuh-tumbuhan atau tanaman yang bernilai ekonomis.

Kewajiban mengeluarkan zakat pertanian secara khusus disebut dalam beberapa ayat al-Qur'an:

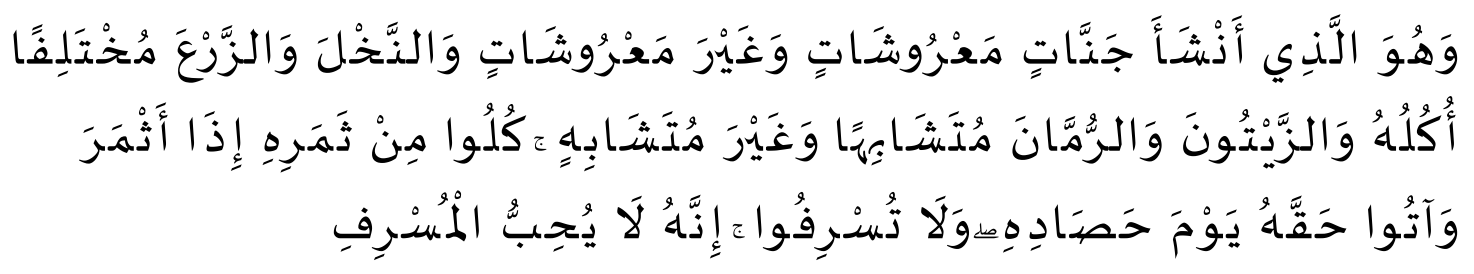

\begin{abstract}
“Dan dialah yang menjadikan kebun-kebun yang berjunjung dan yang tidak berjunjung, pohon korma, tanam-tanaman yang bermacam-macam buahnya, zaitun dan delima yang serupa (bentuk dan warnanya) dan tidak sama (rasanya). makanlah dari buahnya (yang bermacam-macam itu) bila dia berbuah, dan tunaikanlah haknya di hari memetik hasilnya (dengan disedekahkan kepada fakir miskin); dan janganlah kamu berlebihlebihan. Sesungguhnya Allah tidak menyukai orang yang berlebih-lebihan." (Q. S. AlAn'am [6]: 141). ${ }^{5}$
\end{abstract}

Rasulullah SAW bersabda yang artinya:

"Telah diriwayatkan dari Ibnu Abbas bahwasanya tatkala Nabi saw mengutus Mu'az Ibnu Jabal Ra. untuk menjadi qadhi di Yaman. Beliau bersabda: “... Jika ini telah mereka taati, sampaikan bahwa Allah Ta'ala telah mewajibkan zakat pada harta benda mereka, yang dipungut dari orang-orang kaya dan diberikan kepada orang-orang miskin diantara mereka. Jika hal ini mereka penuhi, hendaklah anda hindari harta benda mereka yang berharga, dan takutilah doa orang yang teraniaya karena diantaranya dengan Allah tidak ada tabir pembatas". (H.R. Bukhari). ${ }^{6}$

\section{Pendapat Para Ulama Tentang Zakat Pertanian}

Menurut Imam Abu Hanifah bahwa zakat pertanian harus dikeluarkan dari semua jenis tanaman yang tumbuh di bumi, baik jumlahnya sedikit maupun banyak,

\footnotetext{
${ }^{4}$ M. Arief Mufraini, Akuntansi dan Manajemen Zakat (Jakarta: Kencana Prenada Media Group, 2006), h. 85 .

${ }^{5}$ Kementrian Agama Republik Indonesia, Al-Qur'an dan Terjemahannya (Jakarta: Pustaka Agung Harapan, 2006), h. 146.

${ }^{6}$ Muhammad Ibn Ismā'il Abū 'Abdullāh al-Bukhāri al-Ja'fi, Șahìh al-Bukhāri (Al-Jāmi' aṣ-Ṣaḥi>h alMukhtașar min Umūr Rasūlillāh Ṣallallāh 'Alaihi wa Sallam wa Sunanih wa Ayyāmih), ed. Muhammad Zuhair Ibn Nāṣir (jilid II, t.t.p., Dār Tūq an-Najāḥ, 1422 M), h. 128.
} 
kecuali kayu bakar, rerumputan, bambu parsi, tangkai pohon dan segala tanaman yang tumbuhnya tidak sengaja. Tetapi jika suatu tanah sengaja dijadikan tempat tumbuhnya bambu, pepohonan, dan rerumputan, diairi secara teratur dan dilarang orang lain menjamahnya, maka wajib padanya dikeluarkan zakatnya.

Mazhab Maliki berpendapat bahwa zakat pertanian diwajibkan pada 20 macam tanaman. Beberapa macam dari keluarga biji-bijian, seperti kacang kedelai, kacang tanah, dan kacang pendek, gandum, talas, jagung, tembakau, beras, zaitun dan lobak merah. Adapun jenis buah-buahan yang wajib dikeluarkan zakatnya, yaitu kurma, anggur, dan zaitun.

Menurut Mazhab Syafiei bahwa zakat pertanian hanya dikhususkan untuk makanan yang mengenyangkan, yaitu dari keluarga buah-buahan, seperti kurma dan anggur kering, sedangkan dari keluarga biji-bijian adalah biji gandum, beras, dan semua makanan yang mengenyangkan seperti kacang kedelai dan jagung. Sedangkan, Mazhab Hambali berpendapat bahwa zakat pertanian wajib dikeluarkan dari setiap biji-bijian yang mengenyangkan, dapat ditakar, dan dapat disimpan, misalnya jagung, kacang kedelai, kacang pendek, tembakau, dan beras. ${ }^{7}$

\section{Model Perhitungan Zakat Pertanian Menurut Hukum Islam}

Nisab zakat dihitung dari hasil panen yang sudah dikeringkan dan dibersihkan dari kulit-kulitnya atau senilai dengannya. ${ }^{8}$ Untuk hasil panen yang tidak bisa ditimbang maka nisabnya senilai 5 ausuq. Tanaman seperti padi yang disimpan tanpa dipisahkan dari kulitnya boleh ditunaikan zakat dengan padi dan dihitung senilai nisab beras atau dua kali lipat timbangan beras. ${ }^{9}$

Terdapat perbedaan Ulama dalam menentukan ukuran wasq. Satu wasq setara dengan 60 șă. Menurut Hanafiah 1 wasq adalah $195 \mathrm{~kg}$, sehingga 5 ausuq menjadi $875 \mathrm{~kg}$. Sementara Jumhur Ulama menentukan 1 wasq sebesar 122,4 $\mathrm{kg}$ sehingga 5 ausuq seukuran dengan $610 \mathrm{~kg} .{ }^{10}$ Dalam hitungan Badan Amil Zakat Nasional (BAZNAS) satu $s \bar{a}^{\prime}$ adalah 2,176 kg, maka 5 ausuq adalah 5 × 60 × 2,176 = 652,8 kg beras. ${ }^{11}$ Model hitungan ini sejalan dengan hitungan Imam Yūsuf al-Qaraḍāwi namun hitungan ini direvisi kembali dan menjadi $647 \mathrm{~kg}$ beras. ${ }^{12}$

Jika hasil panen telah melampaui 1 ton $(1000 \mathrm{~kg})$, maka sudah terkena wajib zakat. Contohnya, jika hasil panen seorang petani 10 ton $(10.000 \mathrm{~kg})$, maka $10.000 \times 5 \%$ $=500 \mathrm{~kg}$. Jika dirupiahkan dan harga beras adalah Rp. 10.000,- maka $10.000 \mathrm{~kg}$ x Rp. 10.000,- adalah Rp. 100.000.000,-. Sedangkan 5\% dari Rp. 100.000 .000 adalah Rp.

\footnotetext{
${ }^{7}$ Hafidhuddin D, Zakat dalam Perekonomian Modern, (Jakarta (ID): Gema Insani, 2002), h. 65.

${ }^{8}$ As-Sayyid as-Sābiq, Fiqh as-Sunnah, jilid I, (Cet. XXI; Kairo: Dār al-Fatḥ li al-I'lām al-'Arabiy, 1999),

${ }^{9}$ Ibn al-Muqaddasi Quddāmah, Al-Mugni. (Jilid. III; Kairo: Maktabah al-Qāhirah, 1968), h. 8.

10 Ali Jum'ah, Al-Makāyil wa al-Mawāzin asy-Syar'iyyah, (Cet. II; Kairo: Dār ar-Risālah, 2009), h. 23.

${ }^{11}$ http://pusat.baznas.go.id/zakat-pertanian/. Diakses 21 September 2018.

12 Yūsuf. Al-Qaraḍāwi, Fiqh az-Zakāh, (Cet. XXV; Kairo: Maktabah Wahbah, 2006). h. 382.
} h. 258. 
5.000.000,-. Maka zakatnya adalah $500 \mathrm{~kg}$ beras atau Rp. 5.000.000,-. Zakat yang dikeluarkan bisa berupa hasil panen atau berupa uang tunai seharga kadarnya.

\section{Potensi Zakat Pertanian Di Desa Akeguraci Kecamatan Oba Tengah Kota Tidore Kepulauan}

Desa Akeguraci merupakan salah satu desa yang termasuk dalam wilayah pemerintahan Kota Tidore Kepulauan berlokasi di Kecamatan Oba Tengah Kota Tidore Kepulauan, Desa Akeguraci memiliki jumlah penduduk 603 jiwa dengan jumlah pria 330 jiwa dan wanita 273 jiwa sesuai data profil desa Akeguraci. Desa Akeguraci sebagian besar penduduknya berprofesi sebagai petani, penghasilan yang didapat oleh masyarakat banyak diperoleh dari hasil pertanian. Luas wilayah Desa Akeguraci secara keseluruhan dengan luas wilayah pemukiman warga $1000 \mathrm{~m}$ x $500 \mathrm{~m}$ dan luas wilayah pertanian 36 hektar.

Berkaitan dengan itu, zakat pertanian disyariatkan pada tanaman yang dapat tumbuh dan berkembang. Zakat pada tanaman ini terbagi menjadi dua yakni buahbuahan dan biji-bijian. Keduanya tidak wajib dizakati, kecuali jika sudah memenuhi beberapa kriteria yakni menjadi makanan pokok manusia pada kondisi normal mereka, memungkinkan untuk disimpan dan tidak mudah rusak/membusuk, dapat ditanam oleh manusia, dan mencapai nisab dari hasil panennya.

Desa Akeguraci jika dilihat dari luas wilayah pertanian yang dimiliki oleh warga masyarakat baik lahan pertanian yang sudah digarap dan sudah memperoleh hasil maupun yang belum digarap, keseluruhannya mencapai 36 hektar lahan pertanian. Desa Akeguraci dengan sebagian besar penduduknya berprofesi sebagai petani dengan penghasilan utama berasal dari kelapa yang kemudian mereka olah menjadi kopra. Selain tanaman kelapa para petani juga menanam coklat, cengkeh dan pala. Sebagian besar lahan pertanian yang dimiliki oleh warga ditanami kelapa dan sisanya ditanami coklat, cengkeh dan pala.

Terdapat beberapa alasan mengapa para petani di Desa Akeguraci lebih memilih kelapa sebagai tanaman andalannya, karena tanaman kelapa perawatannya lebih mudah dan praktis tidak merepotkan dibandingkan dengan tanaman lainnya, pengeluaran biaya perawatannya relatif kecil, serta dari segi perolehan hasil pada saat panen, menanam kelapa lebih menguntungkan dari pada tanaman lainnya walaupun pekerjaan pengolahannya menjadi kopra lumayan menguras tenaga dan waktu.

Itulah sebabnya sehingga mereka lebih memilih menanam kelapa dari pada tanaman lain, karena secara ekonomis pengeluaran modal relatif kecil akan tetapi meraih keuntungan yang berlipat ganda oleh karena waktu memanen kelapa bisa 4-5 kali dalam setahun, dan para petani bisa menghasilkan kelapa 5-6 ton dalam sekali panen, jika harga kelapa stabil sesuai standarnya para petani bisa memperoleh keuntungan sekitar Rp. 4.000.000- 5.000.000 per panennya.

Masyarakat Desa Akeguraci menjadikan tanah sebagai standar kekayaan yang dimiliki seseorang. Apabila seseorang memiliki tanah atau lahan pertanian yang luas, maka dia termasuk kategori orang yang memiliki harta dan bagi yang tidak memiliki 
kebun berarti dia tidak memiliki harta atau dikatakan miskin dan terpaksa harus bekerja sebagai buruh pada orang yang memiliki kebun atau mencari pekerjaan lain.

Petani yang memiliki tanah lahan pertanian walaupun hanya setengah hektar namun jika diukur dari hasil pertanian yang didapat setiap kali panen, dapat dikategorikan cukup mampu dalam hal ekonomi. Secara realitas kehidupan sosial ekonomi masyarakat desa Akeguraci yang memiliki tanah lahan pertanian baik hanya setengah hektar sampai enam hektar dikategorikan golongan ekonomi sedang, karena dilihat dari kehidupan masyarakat yang sederhana dan apa adanya tidak sampai pada kategori kelas ekonomi kaya walaupun memiliki lahan pertanian yang luas.

Badan Amil Zakat (BAZ) Desa Akeguraci dalam melakukan pengelolaan zakat, infak dan sedekah telah membuat acuan sebagai tolak ukur pengelolaan zakat, karena sebenarnya telah tergambar dengan jelas sesungguhnya golongan muzakki dan mustahik zakat. Sebab identitas mereka telah teridentifikasi melalui harta atau tanah lahan pertanian yang dimiliki.

Warga masyarakat yang memiliki lahan pertanian walaupun hanya setengah hektar termasuk kategori sebagai muzakki. Sedangkan warga masyarakat yang tidak memiliki harta atau lahan pertanian dikategorikan sebagai fakir miskin yang menjadi penerima zakat (mustahik). Selain fakir miskin yang termasuk dalam kategori mustahik zakat terdapat pula beberapa golongan yang ditetapkan oleh BAZ desa Akeguraci sebagai penerima zakat pada tiap tahunnya yaitu yatim piatu, janda dan fisabilillah.

Pengelolaan zakat dimulai sejak adanya kewajiban zakat sebagaimana diketahui dalam Al-Qur'an surat At-Taubah ayat 60. Di Desa Akeguraci pengelolaan zakat dimulai sejak zaman dahulu, yakni sejak awal migrasi generasi pertama ke tempat itu. Setiap orang muslim pasti menyadari dan mengetahui adanya kewajiban zakat karena berkaitan dengan rukun Islam. Kesadaran itu nampak manakala Bulan Ramadhan tiba, orang Islam tampak mengeluarkan zakat, baik zakat maal maupun zakat fitrah.

Namun sayangnya pengelolaan zakat masih secara tradisional dan pendistribusiannya secara konsumtif belum menjamah pendistribusian secara produktif. Disebabkan karena pemahaman tentang pengelolaan zakat yang masih minim dan juga pembentukan BAZ yang hanya ditunjuk secara langsung pada akhir bulan ramadhan. BAZ yang dibentuk hanya bekerja pada Bulan Ramadhan sehingga pengelolaan zakat hanya terhenti sampai pada penerimaan dan pendistribusian zakat maal dan zakat fitrah. Di luar dari itu, BAZ tidak lagi berfungsi sebagai pengelola zakat. Karena yang diketahui hanya ada zakat maal dan zakat fitrah padahal selain itu ada pula kewajiban-kewajiban zakat lainnya salah satunya zakat pertanian.

Desa Akeguraci termasuk salah satu desa yang memiliki motivasi potensi desa dalam bidang pertanian yang mendukung. Pengelolaan hasil pertanian yang didominasi kelapa mendatangkan keuntungan yang melimpah. Apabila hasil pertanian masyarakat dapat dikelola dengan baik melalui pengelolaan zakat pertanian, maka akan mendatangkan hasil yang maksimal untuk kepentingan fakir miskin secara khusus dan kepentingan masyarakat desa secara umum. 


\section{Implementasi Zakat Pertanian Menurut Pandangan Masyarakat Di Desa Akeguraci Kecamatan Oba Tengah Kota Tidore Kepulauan}

Kewajiban zakat memiliki dua tujuan utama, yakni yang pertama pengeluaran zakat adalah perintah Allah, maka seorang muslim yang telah menunaikannya berarti secara langsung melaksanakan perintah Allah SWT dengan tujuan membersihkan jiwa dan hartanya, dan kedua, pengeluaran zakat adalah perintah Allah sebagai ibadah sosial yang berkaitan dengan kebutuhan manusia, maka setiap muslim yang mengeluarkannya berarti secara langsung meringankan penderitaan orang lain terutama mereka yang kekurangan dan membutuhkan bantuan.

Berbagai jenis harta kekayaan yang wajib dikeluarkan zakatnya disesuaikan dengan situasi dan kondisi pada masa Rasulullah SAW. Dapat dilihat dari ayat-ayat yang mendasari kewajiban membayar zakat masih bersifat global, sehingga menunjukkan keelastisan hukum Islam yang dapat berkembang sesuai dengan perkembangan zaman, serta masih terbuka pintu ijtihad untuk memperluas jangkauan objek zakat sesuai dengan kondisi modern. Hal ini tentunya tidak terlepas dari 'illat hukum yang telah disebutkan dalam nash Al-Qur'an dan Al-Hadits.

Pada masyarakat tradisional manajemen pengelolaan zakat juga masih berbasis tradisional dan memiliki struktur yang sangat sederhana, tetapi memiliki komitmen kuat terhadap suatu tatanan nilai dari prinsip-prinsip masyarakat itu sendiri. Nampak sederhana ajaran Islam pada masyarakat tradisional masih dianggap orisinil dan tekstualis. Masyarakat tradisional ini rentan terhadap perubahan, pertahanan hidup mereka sangat tinggi dan kuatnya etos kerja, akan tetapi tidak tertata dan terorganisir, sehingga nampak mereka bekerja keras namun tidak memperoleh hasil yang maksimal.

Tentang zakat hasil pertanian, beberapa literatur menyebutkan tidak hanya terbatas pada anggur dan kurma. Tetapi juga seperti anggrek, rambutan, mangga, durian, salak, pepaya, dan apa saja hasil pertanian yang memiliki nilai ekonomis dan menghasilkan uang yang banyak bahkan wajib dikeluarkan zakatnya. Berkaitan dengan hal ini, hasil pertanian Desa Akeguraci terdiri dari kelapa, pala, cengkeh, singkong, kacang tanah dan coklat, walaupun tetap didominasi oleh kelapa.

Petani menjadi profesi sebagian besar masyarakat Desa Akeguraci, meskipun tumpuan utama perekonomiannya adalah pertanian namun masyarakat Desa Akeguraci tidak hanya memprioritaskan penghasilannya semata dari hasil pertanian saja, tetapi ada juga penghasilan yang didapat untuk memenuhi kebutuhan hidup sehari-hari melalui berdagang, berternak, menjadi nelayan dengan mencari hasil laut dan lain-lain.

Setelah melihat, mengamati dan meneliti proses pengelolaan zakat dan cara pembayaran zakat hasil pertanian yang dilakukan oleh petani di Desa Akeguraci. Peneliti dapat memberikan penjelasan bahwa cara yang digunakan oleh petani Desa Akeguraci dalam membayarkan zakat hasil pertaniannya, masih menggunakan cara keyakinan hati mereka masing-masing. Sebagian besar petani Desa Akeguraci memahami bahwa zakat yang dikeluarkan pada akhir Bulan Ramadhan sama dengan zakat hasil pertanian. Sehingga zakat yang mereka keluarkan seadanya saja dikarenakan 
pengetahuan tentang zakat pertanian yang masih minim. Petani Desa Akeguraci belum mengetahui cara menghitung zakat pertanian sesuai dengan syariat Islam yang mewajibkan adanya kewajiban zakat pada hasil pertanian pada setiap panennya jika telah mencapai nisab zakat pertanian.

Masyarakat petani Desa Akeguraci, baik dalam menghitung zakat maupun membayarkannya masih relatif tergantung kepada tingkat kesadaran dari para petani sendiri. Bagi petani yang sedikit memahami dan mengerti ketentuan zakat menurut fikih, maka mereka pasti akan mengeluarkan zakat hasil pertanian. Oleh karena itu diperlukan sosialisasi untuk memberikan pemahaman kepada masyarakat tentang adanya kewajiban pembayaran zakat hasil pertanian.

Selain kendala masih minimnya pemahaman masyarakat tentang zakat hasil pertanian, terdapat kendala lainnya yaitu tidak adanya organisasi atau lembaga yang menangani zakat secara khusus di Desa Akeguraci. BAZ yang dibentuk pada Bulan Ramadhan tidak hanya berfungsi dan bekerja melaksanakan tanggung jawabnya pada Bulan Ramadhan saja namun harus juga berfungsi di luar itu, sebagai lembaga tetap dan legal untuk mengelola berbagai jenis zakat. Sehingga pelaksanaan zakat khususnya zakat pertanian sebagai suatu kewajiban dapat dilaksanakan dengan baik.

Eksistensi amil dalam pengelolaan zakat didasarkan pada perintah Allah

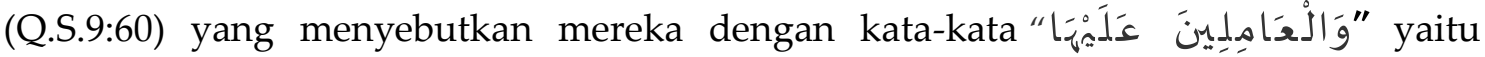
"pengurus-pengurus zakat". Amil memperoleh satu bagian zakat dari delapan bagian sebagaimana dalam ayat tersebut di atas. Qardawi menafsirkan bahwa amil adalah orang-orang yang ditugaskan oleh imam/pemerintah untuk mengambil, menuliskan, menghitung, dan mencatat zakat yang diambil dari muzakki untuk diberikan kepada yang berhak menerimanya. ${ }^{13}$

Menurut Wahbah, bagian yang diberikan kepada panitia dikategorikan sebagai upah atas kerja yang dilakukannya, bukan berdasarkan status tetapi terkait dengan profesionalisme. Profesionalisme amil dalam mengelola zakat merupakan bagian penting dalam sebuah lembaga zakat, sehingga perekrutannya didasarkan pada kriteria tertentu, yakni memiliki pengetahuan dan pemahaman tentang hal ihwal zakat, bersifat amanah, jujur dan adil serta setia dan sanggup untuk bekerja full time dalam mengelola zakat. $^{14}$

Sesuai pendapat Wahbah di atas, lembaga pengumpul zakat ditingkat desa yang dibentuk secara khusus untuk menangani zakat diharuskan memiliki persyaratanpersyaratan tertentu, sehingga dalam hal pengelolaan zakat juga tidak akan menimbulkan kecurigaan-kecurigaan di masyarakat. Persyaratan-persyaratan yang harus dipenuhi sebagai pengelola zakat misalnya, orang-orang yang paham tentang tata cara pengelolaan zakat sesuai dengan syariat Islam, memahami cara pendistribusian zakat kepada golongan yang membutuhkan, pemanfaatan zakat yang telah diterima

\footnotetext{
13 Yusuf al-Qardhawi, Hukum Zakat, Studi Komparatif Mengenai Status dan Filsafat Zakat Berdasarkan al-Qur'an dan Hadis, Terjemahan Salman Harun dkk, (Jakarta: Litera Antar Nusa dan Mizan, 1999), h. 112.

${ }^{14}$ Wahbah Zuhayly, Zakat Kajian Berbagai Mazhab, (Bandung: PT. Remaja Rosdakarya, 1997), h. 283.
} 
agar perekonomian desa menjadi lebih baik, serta diharuskan orang-orang yang amanah dan bertanggung jawab dalam menjalankan tugasnya.

Kelembagaan zakat baik dalam bentuk badan maupun lembaga dengan sistem manajemen yang profesional dan transparan merupakan salah satu prasyarat terwujudnya zakat untuk perubahan sosial dan lebih luasnya untuk keadilan sosial. Mustahil memang jika ingin mengembangkan zakat sebagai alat perubahan jika hanya mengandalkan pada upaya-upaya individu untuk mengatasi kemiskinan dengan memberikan zakat secara langsung kepada fakir miskin tanpa melalui suatu lembaga.

\section{KESIMPULAN}

Desa Akeguraci jika dilihat dari luas wilayah pertanian yang dimiliki oleh warga masyarakat baik lahan pertanian yang sudah digarap dan sudah memperoleh hasil maupun yang belum digarap, keseluruhannya mencapai 36 hektar lahan pertanian. Desa Akeguraci dengan sebagian besar penduduknya berprofesi sebagai petani dengan penghasilan utama berasal dari kelapa yang kemudian mereka olah menjadi kopra. Selain tanaman kelapa para petani juga menanam coklat, cengkeh dan pala.

Desa Akeguraci termasuk salah satu desa yang memiliki motivasi potensi desa dalam bidang pertanian yang mendukung, dikarenakan profesi sebagian besar masyarakat desa sebagai petani dengan hasil utama kelapa. Pengelolaan hasil pertanian tersebut mendatangkan keuntungan yang melimpah. Apabila hasil pertanian masyarakat dapat dikelola dengan baik melalui pengelolaan zakat pertanian, maka akan mendatangkan hasil yang maksimal untuk kepentingan fakir miskin secara khusus dan kepentingan masyarakat desa secara umum.

Setelah melihat, mengamati dan meneliti proses pengelolaan zakat dan cara pembayaran zakat hasil pertanian yang dilakukan oleh petani di Desa Akeguraci. Peneliti dapat memberikan penjelasan bahwa cara yang digunakan oleh petani Desa Akeguraci dalam membayarkan zakat hasil pertaniannya, masih menggunakan cara keyakinan hati mereka masing-masing. Sebagian besar petani Desa Akeguraci memahami bahwa zakat maal yang dikeluarkan pada akhir Bulan Ramadhan sama dengan zakat hasil pertanian. Sehingga zakat yang mereka keluarkan seadanya saja dikarenakan pengetahuan tentang zakat pertanian yang masih minim. Petani Desa Akeguraci belum mengetahui cara menghitung zakat pertanian sesuai dengan syariat Islam yang mewajibkan adanya kewajiban zakat pada hasil pertanian pada setiap panennya jika telah mencapai nisab zakat pertanian.

Masyarakat petani Desa Akeguraci, baik dalam menghitung zakat maupun membayarkannya masih relatif tergantung kepada tingkat kesadaran dari para petani sendiri. Bagi petani yang sedikit memahami tentang ketentuan zakat menurut fikih, maka mereka pasti akan mengeluarkan zakat hasil pertanian. Oleh karena itu diperlukan sosialisasi untuk memberikan pemahaman kepada masyarakat tentang adanya kewajiban pembayaran zakat hasil pertanian. 


\section{REFERENSI}

Ali, Nurdin Muhammad. Zakat Sebagai Instrumen Dalam Kebijakan Fiskal. Jakarta: PT. Raja Grafindo Persada, 2006.

al-Ja'fi, Muḥammad Ibn Ismā'il Abū 'Abdullāh al-Bukhāri. Șaḥi ’h al-Bukhāri (Al-Jāmi' aṣȘahi>h alMukhtașar min Umūr Rasūlillāh Șallallāh 'Alaihi wa Sallam wa Sunanih wa Ayyāmih), ed. Muḥammad Zuhair Ibn Nāṣir. jilid II, t.t.p.: Dār Tūq an-Najāḥ, 1422 M.

Al-Qaraḍāwi, Yūsuf. Figh az-Zakāh. Cet. XXV; Kairo: Maktabah Wahbah, 2006.

-, Hukum Zakat: Studi Komparatif Mengenai Status dan Filsafat Zakat Berdasarkan Alquran dan Hadits. terj. Salman Harun, dkk. Cet. VII; Jakarta: PT. Pustaka Lentera Antar Nusa, 2004.

Aminuddin dan Zainal Asikin, Pengantar Metode Penelitian Hukum. Cet. III; Jakarta: PT. Raja Grafindo Persada, 2006.

Anshori, Abdul Ghofur. Hukum dan Pemberdayaan Zakat; Upaya Sinergis Wajib Zakat dan Pajak di Indonesia. Cet. II; Yogyakarta: Pilar Media, 2006.

Ash Siddieqiy, Hasbi. Pedoman Zakat. Semarang: PT. Pustaka Rizki Putra. 1999.

As-Sābiq, As-Sayyid. Fiqh as-Sunnah. Cet. XXI; Kairo: Dār al-Fath li al-I'lām al-'Arabiy, 1999.

az-Zuhaily, Wahbah. Al-Figh al-Islami wa Adillatuhu. Juz II; Beirut: Dar al-Fikr, t.th.

Zakat Kajian Berbagai Mazhab. Bandung: PT. Remaja Rosdakarya, 1997.

Beuley, Abdullhaq. Restorasi Zakat Menegakkan Kembali Pilar yang Runtuh. Jakarta: Pustaka Adina, 2001.

El-Madani, Figh Zakat Lengkap. Cet. I; Yogyakarta: Diva Press, 2013

Fakhruddin. Figh dan Manegemen Zakat di Indonesia. Malang: UIN-Malang Press, 2008.

Hadad, Yamin. Dinamika Pengelolaan Zakat di Indonesia. Cet. I; Tangerang Selatan: Anugrah, 2017.

Hafifuddin, Didin. Zakat Dalam Perekonomian Modern. Cet. I; Jakarta: Gema Insani Press, 2002.

Jum'ah, Ali. Al-Makāyi $>l$ wa al-Mawāzi $><n$ asy-Syar'iyyah. Cet. II; Kairo: Dār ar-Risālah, 2009.

Karim, Adiwarman Azwar. Sejarah Pemikiran Ekonomi Islam. Cet. V; Jakarta: RajaGrafindo Persada, 2012.

Kementrian Agama Republik Indonesia. Al-Qur'an Dan Terjemahannya. Jakarta: Pustaka Agung Harapan, 2006.

Khasanah, Umrotul. Manajemen Zakat Modern. Malang: UIN Maliki Press, 2010. 
Masudi, Masdar F. Menggagas Ulang Zakat Sebagai Etika Pajak dan Belanja Negara Untuk Rakyat. Bandung: Mizan, 2005.

Mufraini, M. Arief. Akuntansi dan Manajemen Zakat. Jakarta: Kencana Prenada Media Group, 2006.

Muhammad, Sahri. Mekanisme Zakat Permodalan Masyarakat Miskin Pengantar Untuk Rekonstruksi Kebijakan Pertumbuhan Ekonomi. Malang: Bahtera Press, 2006.

Qadir, Abdurrahman. Zakat Dalam Dimensi Mahdhah dan Sosial. Jakarta: Raja Grafindo, 1998.

Soekanto, Soerjono dan Sri Mamudji, Penelitian Hukum Normatif Suatu Tinjauan Singkat. Jakarta: Rajawali Press, 1990.

Sugiyono. Metode Penelitian Kuantitatif Kualitatif dan R \& D. Cet. VI; Bandung: Alfabeta, 2009.

Thonthowi, Muhammad Sayyid. Al-Fiqh al-Musayyar. Cet. I; Kairo: Dar as-Sa'adah, 2001. http://pusat.baznas.go.id/zakat-pertanian/. Diakses 21 September 2018. 
Nursinita Killian 